\title{
中职学校体育课程设置改革的设想
}

\author{
龙成理 \\ 湛江机电学校 \\ DOI:10.32629/er.v1i3.1515
}

[摘 要] 在中职学校的日常教学中,体育课程教学是一项重要的内容,但一些中职学校并不能正确地认识体育课程设计的关 键所在,进而导致在体育课程设置中存在着较为明显的不足。因此, 我们有必要采取有效措施对中职学校体育课程设置进行改 革和创新,让中职院校学生得到多方面的发展。

[关键词] 中职院校; 体育课程; 设置; 改革

为了有效带动中职教育的发展, 中职院校应结合学校的 实际情况, 做出科学的规划。在中职学校教学的过程中, 应高 度重视学生的体质和体能, 故而体育课程的教学就显得尤为 重要, 但是从当前的情况来看, 在中职院校的体育课程设置 方面, 还存在着诸多的问题, 因此必须要将课程的改革提上 日程。

\section{1 中等职业学校体育课程内容的现状}

1.1 体育课程内容现状分析

在一些中职院校的体育课程中, 主要开设了田径、排球、 篮球、足球、羽毛球、乒乓球、健美操、体育舞蹈等多个教 学内容, 因为课程内容设置的情况直接影响了课程设置的科 学性, 所以, 在中等职业院校教学中, 学生的专业应与体育课 程的内容设置保持紧密的联系。另外, 其还需满足学生未来 的就业需要, 不能单一的按照教学大纲开设课程, 必须结合 教学大纲和学生实际来设置课程相关内容。

\section{2 体育课程内容时段安排}

大纲要求中职一年级和二年级开设体育课程, 同时以学 院教务部门的要求为基础, 安排体育课周教学任务。在体育 课内容的安排上, 需充分结合学生的兴趣和爱好, 引导学生 自主选择体育学习的项目。在学生一年级和二年级的学习中, 主要采用体育选修的方式。但实际上, 某些学校则是以教师 的意愿来安排教学的具体内容。在中职院校的改革发展中, 第一学年可为学生安排统一的体育课程, 之后按照学生的兴 趣爱好, 引导学生自主选择不同的学习项目, 直至第二学期 课程结束。

\section{3 体育课程内容满意度调查分析}

笔者针对学生对体育课程教学内容的满意度进行了调 查, 其中, 中职男生对课程表示满意的占 30\%, 表示不满意的 占 $65 \%$, 表示无所谓的占 $5 \%$ 。女生中, 表示满意的占 $28 \%$, 表 示不满意的占 $60 \%$, 表示无所谓的占 $12 \%$ 。由该调查可以看出, 大部分中职院校的学生对体育课并不满意, 产生这一状况主 要是由于体育课的内容不是学生感兴趣的内容, 很多内容在 中小学已经学过, 而教学的内容依然以教材中所涉及的内容 为主, 过于依赖教材和教师, 没有充分尊重学生专业和地区 之间的差异性, 所以无法对学生产生较大吸引力。

\section{4 体育课程考核、评价分析}

在体育期末测评当中, 教师需重视学生运动技能的掌握 情况, 其一方面可以提升学生的运动能力, 另一方面也能够 培养学生参与体育运动的意识, 使学生能够更加熟练地掌握 体育项目的技巧, 从而使其能够树立终身体育的意识。但很 多体育教师认为, 学生体育期末测试只是对本学期学生体育 学习情况的一种检验。一些体育教师在期末考核时, 将学生 体育学习的出勤率作为重要的考核项, 核查其出勤率是否能 够达到基本的要求, 并以学生的出勤情况给出学生的期末成 绩。这就导致一些出勤率低于三分之二的学生, 在体育课程 中获得不及格的成绩, 甚至可能直接停考。

总体来看, 中职院校的体育课程学习质量不高, 在内容 上与小学和中学的体育教学非常相似, 故而这种状况对学生 的学习兴趣和积极性构成了非常显著的影响。大多数学生无 法将更多的精力和注意力放在体育学习当中, 教师与学生之 间无法充分地在课堂上形成良好的配合, 教师教授的内容和 学生学习的内容差异较大, 学生无法学到自己感兴趣的内容, 且教师也不能将自己想要教授的内容很好地传授给学生, 甚 至还有一部分教师将体育项目的技术要领以小视频的方式 传授给学生, 学生在临近考试时, 只要稍加练习, 就能通过期 末考试, 这种现象在武术和舞蹈及健美操当中比较常见。一 些中职院校对学生的体育兴趣并不十分关注, 这导致学生不 能全面的掌握体育课上传授的知识, 而这对学生的身体健康 也构成了较为负面的影响。

\section{5 体育课程内容实用性和发展性较为薄弱}

在体育课程设置方面, 若要保证课程的内容具有较高的 价值的同时, 还能促进学生的个性化发展, 让学生实现自己 的生活目标, 就必须要在课程内容上更加突出其实用性和具 体性, 且课程目标的设置也应充分地体现其社会价值。然而 实际情况是, 在中职院校的体育课程设置中, 存在着与实际 相脱节的情况, 不利于学生的个性化发展, 且课程内容的设 置也不具有实用性, 严重阻碍了学生的全面发展。

\section{2 中等职业学校体育课程内容设置改革规划}

现阶段, 我国中职院校的体育课程内容设置上存在着十 分明显的不足, 这也在一定程度上影响了体育教学的水平, 
因此我们必须采取有效措施, 积极地做好中职院校体育课程 设置的改革规划工作, 以优化体育教学的整体水平。

2.1 体育课表中融入职业体能的内容

在中职院校体育课程内容设置的过程中, 应充分考虑到 课程的实用性及发展性, 这样才能够更好地保证学生能够适 应日后的职业要求, 为学生的个人发展创造良好的条件。另 外, 还可以鼓励学生自主创业。在体育课程教学中, 教师可采 取有效措施积极改革和创新传统的教学方式和方法。相关文 件中明确指出, 体育教学应立足于学生的终身发展, 不断增 强学生的专业能力, 提高学生的基本文化素质, 从而使学生 满足社会对人才的要求。

中职院校在教育教学中, 要为社会输送更多的可用之才, 同时还要帮助学生获得更好更大的就职平台。而这也成为了 设置体育课程教学目标的基础和依据。

为了推动学生身心健康的建设, 加大中职院校学生参加 体育运动的热情, 教师在教学的过程中, 可开展多种形式的 体育实践活动, 从而起到培养学生运动兴趣和习惯的目的, 帮助学生养成终身体育的意识。也就是说, 中职院校体育课 程一方面要重视学生能力的培养, 另一方面还要保证体育教 学与学生日后的工作特点相适应, 全面地展现体育教学的实 用性和职业性。

2.2 以培养职业体能为目标, 开设特色体育课程内容

在中职院校当中主要的课程有导游、建筑装饰、旅游管 理、工程造价、市政工程、建筑设备安装、机电、无人机维 修、会计电算化、电子商务、学前教育、汽车护理与维修等 多个专业。同时还设置了 $3+2$ 的会计专业、服装设计、机电 一体化、艺术设计、动漫制作、计算机应用和 $3+4$ 的旅游韩 语专业等。以身体姿态和学生的职业特点来划分, 可将其分 为综合型、坐立型和站立型三种形式。且不同的姿势类型与 工作者从事的职业有着非常密切的联系, 故而对其身体素质 和环境适应能力的要求也有所不同, 从整体上来看, 在职业 发展中, 需要学生的背肌能够承受较大的静态力, 且还应具 备重复操作的能力, 人体需对湿热环境具有较高的耐受力, 其他肌肉群还要在一定时间内保持工作姿势。

2.3 对体育课程考核与评价的方式进行改革和创新

对于中职院校的体育课程考核评价, 其主要的目的是检 验体育课程的教学质量和教学效果, 另外其也是对学生是否
认真学习, 教师是否教学到位的重要评判, 可以说是教师对 学生多种活动进行有效考核的重要方式。这一方式能够起到 提升教学质量和教学效率的作用。可以说其是中职院校教育 教学中不可缺少的一部分, 但是我们不能将其误认为是体育 教学的主要目标。采取体育期末考核的方式能够帮助教师全 面了解学校的体育教学情况, 并在一定程度上带动学生更加 积极地加入到体育活动当中, 提升学生的体育技能, 从而使 体育教学的成果得到检验和反馈, 不断完善体育教学的质量 及水平。

现如今, 中职院校的体育课程考核与评价标准还存在着 一定的不足, 需要对其进行科学和有效的调整, 可在以往评 价标准的前提下, 创建一个综合性更强的评价机制, 将学习 过程和考核结果均纳入到考核体系当中。

结果性评价主要是对学生的期末考核成绩进行评价; 而 过程性评价则是为学生创建健康档案库, 并对学生进行针对 性的评价。而为了更好地研究不同体育项目的基本特征, 还 需制定一个较为完善的统一考核评价标准。规定考勤+课程 表现占学生总分的 10\%, 理论知识占考核总分的 10\%, 身体素 质占考核总分的 $10 \%$, 技术能力占考核总分的 $40 \%$, 专业体能 占考核总分的 $30 \%$, 这种综合性的考核方式更加科学合理。

\section{3 结语}

中职院校体育教学是中职院校教育教学的重要组成部 分, 但是在现阶段的中职院校的体育教学中, 课程设置不是 十分合理, 其无法充分满足学生的兴趣爱好, 且学生的满意 度也不是很高, 这就影响了学生学习体育和参与体育的热情, 对此, 我们必须采取有效措施, 积极地改革中职院校体育课 程设置, 使中职院校体育课程的内容能够与学生的兴趣爱好 相吻合, 并最终为学生日后的职业道路和个人的全面发展创 造有利条件。

\section{[参考文献]}

[1]张颖.浅谈中职学校体育教学的创新与改革 [J].小作 家选刊,2016(27):36.

[2]苏鹏飞.浅析中职学校体育教学的改革与创新 [J].科 教导刊:电子版,2017(32):241.

[3]汪林桥.浅谈中职体育教学的改革创新[J].读写算: 教 师版,2017(34):34 